Revista de la red interuniversitaria de estudios sobre las literaturas rioplatenses contemporáneas en Francia

$14 \mid 2016$

Levrero

\title{
"¿Y dónde está el centro ? Eso, ¿dónde está el centro". Sobre la obra de Mario Levrero
}

\section{Loreley El Jaber}

\section{OpenEdition}

\section{Journals}

Edición electrónica

URL: http://journals.openedition.org/lirico/2325

DOI: $10.4000 /$ lirico.2325

ISSN: 2262-8339

Editor

Réseau interuniversitaire d'étude des littératures contemporaines du Río de la Plata

Referencia electrónica

Loreley El Jaber, « ¿Y dónde está el centro ? Eso, ¿dónde está el centro". Sobre la obra de Mario Levrero », Cuadernos LIRICO [En línea], 14 | 2016, Publicado el 07 junio 2016, consultado el 24 septiembre 2020. URL : http://journals.openedition.org/lirico/2325; DOl : https://doi.org/10.4000/ lirico.2325

Este documento fue generado automáticamente el 24 septiembre 2020

\section{cc) (1) 8}

Cuadernos LIRICO está distribuido bajo una Licencia Creative Commons Atribución-NoComercial-

SinDerivar 4.0 Internacional. 


\section{"¿Y dónde está el centro ? Eso, ¿dónde está el centro". Sobre la obra de Mario Levrero}

Loreley El Jaber

\section{REFERENCIA}

La máquina de pensar en Mario. Ensayos sobre la obra de Levrero. Buenos Aires: Eterna Cadencia Editora, 2013, 265 p.

1. 
La máquina de pensar en Mario no es una recopilación de ensayos sobre la obra del escritor uruguayo Mario Levrero; es diría más bien- en principio un intento por reconstruir la dispersa bibliografía crítica sobre toda la obra de Levrero, así como de realizar un mapeo -hasta la aparición de este libro ausente- de los modos que encontró y encuentra actualmente la crítica a la hora de leer a este autor. Así, por medio de fragmentos de prólogos, de artículos en periódicos y en revistas académicas, de notas en revistas culturales, de libros críticos y de ensayos, De Rosso, responsable de la selección de textos que componen este libro, ofrece al lector un abanico de voces críticas sobre todos los textos de Levrero. Pero también busca cubrir vacíos; a esos fragmentos, en su mayoría

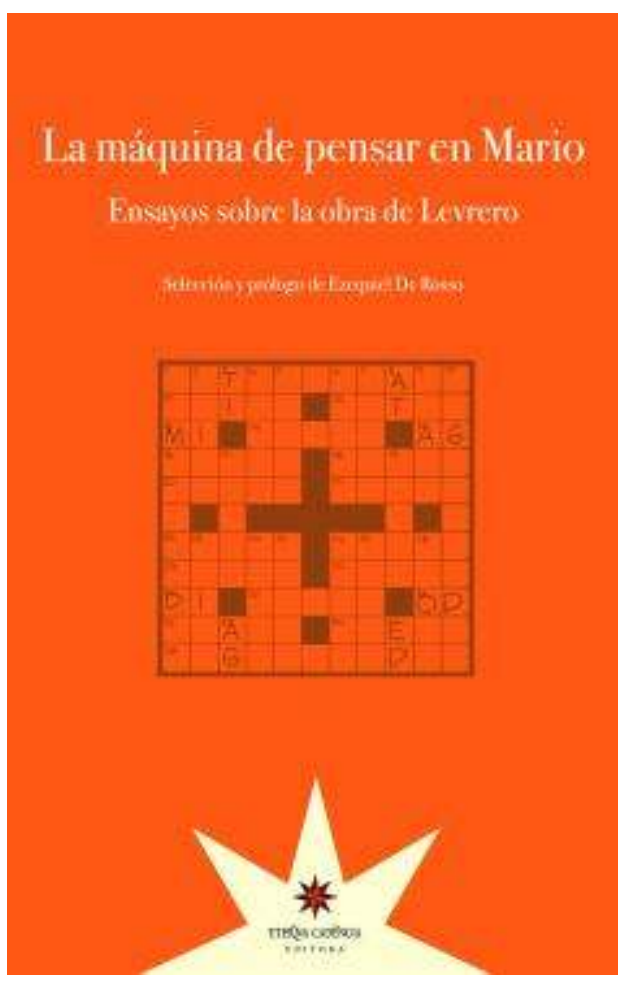
contemporáneos a la publicación de los textos y que elige agrupar hacia el final, agrega artículos escritos o reescritos especialmente para la ocasión y otros fundacionales de la obra de Levrero, junto con aquéllos que proponen nuevos modos de entrar a la obra del uruguayo. Si gran parte de esos ensayos resultan novedosos no es sólo por la originalidad de sus ideas o sus planteos -aspecto que los aúna y que vale destacar tanto por la homogeneidad que le da al libro como por la dimensión que le confiere a cada ensayo en sí mismo- sino también por el problema a abordar. Es evidente que al editor le interesa el problema de los géneros, al menos en lo que respecta a la obra de Levrero (aunque podría elucubrarse que esa preocupación la excede). Se hace evidente al leer el libro, al detenerse en su artículo y en su trayectoria crítica, al reparar en el título elegido y en esa elocuente referencia a La máquina de pensar en Gladys. Si, como señala Roberto Echavarren, dicho libro publicado en 1970 "efectúa cierta dispersión del imaginario, dado que cada cuento remite a un género diferente", la elección del título y la "mala cita" de De Rosso parecen seguir el mismo camino. De este modo, La máquina de pensar en Mario entra a tal problemática abordando también los géneros que podrían pensarse marginales, en especial si nos atenemos a las palabras y reflexiones del propio autor sobre ellos, es decir el género policial, la ciencia ficción, la historieta, por mencionar los más representativos.

2 Si dije al comienzo que este libro no es una mera recopilación de ensayos, fue precisamente teniendo en mente este deseo de completud, este afán por abarcar toda la producción de Levrero, literaria o no; por eso entra también la gran entrevista epistolar que le realiza Pablo Rocca y que él responde con método (aún cuando se ofusque, retruque e ironice) ; por eso también se elige el crucigrama para la tapa, que el mismo Mario componía para la editorial Juegos de mente ; por eso se agrega en el prólogo al menos una de las letras que Levrero escribió para el músico Leo Masliah. Los géneros, todos ellos, intentando desentrañar la máquina Levrero. Como no podía ser de otro 
modo, y para ser fiel a uno de esos géneros llamados menores, a una máquina sólo puede descifrarla otra máquina, la cual, si bien puede ser de igual o mayor dimensión, claramente debe poseer mayor complejidad. Una suerte de máquina que lo abarque todo ; con ese imposible juega este libro : La máquina de pensar en Mario.

\section{2.}

3 Hacia el final de la entrevista que le realiza Pablo Rocca en 1992, y que por primera vez se publica aquí de forma completa, Mario Levrero ironiza sobre la tarea de la crítica :

Si Pablo tiene oportunidad de hablar con ella [mi compañerita de banco en Peñarol], M.S.A.M tal vez le cuente que ella tenía un gato llamado Bijou (o Biyú), y es posible que conserve alguna foto de ese gato. Observando la foto con lupa, Pablo podrá descubrir que en las manchas de su pelaje se insinúan unas formaciones que evocan algunas imágenes; vistas al microscopio, estas imágenes se vuelven completamente nítidas $\mathrm{y}$, en su conjunto, muestran puntualmente los hechos que luego aparecerán en mi novela La ciudad.

Calculo que una vez publicado este importante descubrimiento de Pablo, un crítico radicado en U.S.A. encontrará la forma de hacerse con copias de la foto del gato, y las hará examinar con instrumentos, de mayor precisión, que hay allá. Así podrá descubrir que el gato no era tal, sino un hipopótamo, y que las imágenes impresas en la dura piel no son exactamente las de La ciudad (...), lo que dará origen a una pequeña monografía sobre la influencia de "Los últimos días de Pompeya", de Bulwer Lytton, en El lugar, de Mario Levrero.

Sin duda, esto va a generar una ardiente polémica entre Rocca y este otro crítico, durante la cual se harán más y más aportes esclarecedores, de forma tal que, cuando un lector tome en sus manos un libro cualquiera de Levrero, podrá estar seguro de la clase de terreno que está pisando. ${ }^{1}$

4 Más allá de su humor corrosivo y de su visión de la crítica, enfocada en este caso en la figura del entrevistador, hay una condensación de sentido que alude a su obra. ¿De qué habla aquí Levrero? Lo que dice con claridad es que no hay afuera; el exterior, lo circundante, construyen claves de lectura que fuerzan el texto en su ajenidad. Para decirlo con sus palabras : "No hay nada fuera de los textos que diga más o mejor que los textos" (107). Se lee aquí una declaración de principios que aboga por la interioridad, por una textualidad que se basta en y por sí misma. Esta anécdota inventada, esta humorada sarcástica sobre la crítica no hace más que hablar de una poética del adentro, del repliegue. El texto, la escritura, la mano que elabora el trazo, la pluma que lo efectiviza, el sujeto detrás de la palabra escrita o de la no palabra. Si el yo limita, hay que matarlo porque no sirve. En eso se basa su "teoría del suicidio perfecto". La multiplicidad corroe la posibilidad de una identidad unívoca, el afuera ofrece "aportes esclarecedores" que le permitirán al lector sentir que se halla en "terreno seguro": nada más alejado de la intención de Levrero. Ni el tiempo, ni el espacio, ni el sujeto, ni lo real, nada es límpido, unívoco, todo se halla desdibujado, desubicado, fracturado, el mundo es inestable (de hecho el gato podría ser un hipopótamo), por eso no hay anclaje ni lugar del cual asirse ; bombardeada la intención y la forma, extremado el yo, si hay sentido en el vacío, este está, como señala Reinaldo Laddaga, en su potencialidad. Dice Levrero: "Se me ocurre que la verdad profunda de las cosas es necesariamente difusa, imprecisa, inexacta"; siguiendo su lógica, sólo en el vaciamiento, en el horadar constante de lo real puede hallarse un modo de conocimiento. 


\section{3.}

5 La máquina de pensar en Mario parece haber sido pensada respetando los vaivenes de esa poética ; como si se quisiera descubrir la verdad que esconde el pliegue (si es que existe tal verdad) sin desarmarlo ni rediseñar su entramado, cada artículo aborda ese afán epistemológico del que hablábamos sin perderse en el intento. Pablo Fuentes dice con acierto : "los textos se construyen de costado"; si bien lo menciona en relación con las trayectorias de los protagonistas y de los narradores, esa deriva constante y constitutiva de esos sujetos, esa "construcción de costado" que aborda Fuentes, ese juego con la liminaridad, es uno de los ejes del trabajo escriturario de Levrero. Por su parte, Hugo Verani busca dar cuenta del "mundo pesadillesco de Levrero". Su impecable análisis sobre la trilogía involuntaria (La ciudad, El lugar y París) pone en escena lo que podría llamarse una lógica de lo inestable, condición necesaria para la despersonalización y para lo que el crítico registra como el "trastocamiento perturbador del yo".

"Sí, ahora veo que (...) yo mismo soy un extraño para mí. Tan ajeno como esta ciudad, como esta casa, como aquella otra ciudad y sus selvas y túneles. El extraño soy yo". 2

La desestabilización del yo es trabajada por Verani en sintonía con esos hombressonámbulos en ámbitos nebulosos, desrealizados. La escritura de Levrero elige para esos deambulantes espacios que oficiarán de reduplicadores (si no también de propiciadores) de ese identitario vaciamiento del ser. A ellos se dedica Martín Kohan, quien circunscribe lo pesadillesco a la idea misma de ciudad. Aunque en ocasiones marcada por referencialidades, la ciudad "falta, se disuelve, se ausenta (...). Los personajes presuponen una ciudad y al actuar de esa forma no hacen otra cosa que subrayar su falta" (114). No hay espacios acogedores, sólo transitoriedad y asfixia ante una espacialidad "imprecisa en su existencia", dice Kohan. La ciudad, la calle, la casa, no hay resguardo. Permanecer en la casa es, como lo describe Sergio Chejfec, entregarse a la tumba, "sitio de reclusión y escenario de manías"; dejar la casa es abandonarse a un afuera que expulsa ; salir a calle, tal como lo confiesa el narrador del "Diario de la beca", deber ser como morirse, o mejor dicho: "morirse debe ser como salir a la calle (...) pero sin la esperanza de retornar a casa" (196). Sin asidero, vagabundos del sentido, los sujetos derivan; así construye Levrero lo que Chejfec describe con claridad como "relatos de la incomodidad". A ello también se dedica Adriana Astutti. A partir del final del cuento "La máquina de pensar en Galdys", "la casa se estaba derrumbando", Astutti lee la escritura de Levrero como una escritura postderrumbe : una escritura que se impone y se vacía en su acontecer; para decirlo con sus palabras: "una escritura que arma sentido contra la voluntad de sinsentido del escritor" (207). Sobre esa voluntad de vacuidad discurre asimismo Reinaldo Laddaga : "no hay nada en nada de especial", "la disposición del que sostiene la experiencia es el horror del evento". El evento, concebido en su matiz horroroso, recuerda el dictamen del narrador de La novela luminosa sobre el texto que lee de Rosa Chacel : "lo peor del libro es la interrupción constante de la acción"3. La casa se derrumba, la cuerda del aljibe se ha roto ("El sótano"); sea que reparemos en el final de un cuento o de otro, como señala Roberto Echevarren en su artículo: "no hay final, salvo que la cuerda se rompe (...). El evento alcanza su propio despliegue, se vuelve un peso o un espesor" (240). Ese sinsentido de la acción es uno de los ejes abordados por Oscar Steimberg en su texto sobre la historieta en Levrero, dado que lo que él lee allí es una suerte de lógica 
del absurdo donde "todo puede existir en estado de desconexión", donde la comunicación es imposible y donde lo onírico encuentra su lugar sin dificultad; en suma, donde el evento en sí se ve horadado en su imposibilidad, y donde el despojo, la yuxtaposición y también el humor, como argumenta Luciana Martínez en su artículo sobre la ciencia ficción, se convierten en "caminos epistemológicos".

7 Son varios los momentos en que el propio Levrero ha confesado su preocupación por el estilo por sobre la anécdota ; atendiendo a esto De Rosso plantea que la permanencia del relato policial en su obra permite pensar en la existencia de "una necesidad inscripta en la forma misma". A partir de un detallado trabajo estilístico, De Rosso lee las novelas policiales de Levrero como el espacio en el que este autor "resuelve el pasaje entre las distintas cristalizaciones de su estilo" (162).

En base a un libro de crítica sobre Samuel Beckett, padre del absurdo, que viene leyendo, el narrador de La novela luminosa explica que, si bien el arte no debe medirse por sus contenidos, no puede negarse el hecho de que hay significados en la obra del artista, aún cuando estos no justifiquen la existencia de la misma, y remata : yo mismo "he dicho y escrito 'si yo quisiera transmitir un mensaje ideológico, escribiría un panfleto' (...). Pero eso no quiere decir que en mi literatura no se expongan ideas y que no valga la pena mencionar esas ideas". ${ }^{4}$ En relación con ello, puede pensarse la lectura que ofrece Juan Carlos Mondragón al abordar el mundo ficcional levreriano, su extrañamiento y la fractura del tiempo como "sutiles formas de la violencia".

La máquina de pensar en Mario expone muchas y diversas ideas y, fiel a la atmósfera de Levrero, ofrece recorridos pero no construye finales. Quizás por eso, cuando parece alcanzarse un cierre, de esos que clausuran el sentido, Astutti, en un juego que podría expandirse a todo el libro, tira la piedra : $Y$ sin embargo... Y sin embargo".

\section{NOTAS}

1. Ezequiel De Rosso, La máquina de pensar en Mario, Buenos Aires: Eterna Cadencia, 2013, pp. 110-111.

2. El lugar, citado en Ezequiel De Rosso, op. cit., p.55.

3. Mario Levrero, La novela luminosa, Barcelona, Random House Mondadori, 2008, p. 133.

4. Mario Levrero, La novela luminosa, op. cit., p.125.

\section{AUTORES}

\section{LORELEY EL JABER}

Consejo Nacional de Investigaciones Científicas y Técnicas (CONICET) 
Universidad de Buenos Aires (UBA)

es 